\title{
Establishment of Technological Stages for Obtaining Some Grafted Tomato Seedlings (Dutch Scion x Romanian Rootstocks)
}

\author{
Dorin SORA
}

Department of Horticultural Cultures in Protected Spaces, Research and Development Institute for Processing and Marketing of Horticultural Products - Horting, Bucharest, Romania *corresponding author: doltumadalina@yahoo.com

\begin{abstract}
The tomatoes are valuable vegetables, with highest share in Romanian crops from protected spaces. The grafting is a vegetative multiplication method that induces or improves some qualities of the plants (vigor, resistance to soil diseases and pests, resistance to abiotic factors, quantity and quality of fruit production). The research aim has been to establish the technological stages for producing of Dutch scion and Romanian rootstock seedlings from Solanum lycopersicum L. species, to obtain some compatible phenotypes for grafting. This research has been conducted in a greenhouse of the Horting Institute Bucharest. The experience was carried out on a tomato cultivar collection consisting from a Dutch scion ('Abellus' $F_{1}$ hybrid) and three Romanian rootstocks (' $\mathrm{L}_{542},{ }^{\prime}, \mathrm{L}_{543}{ }^{\prime}, \mathrm{L}_{544}$ '). The scion and rootstock diameters have been correlated for manual grafting, cutting at 45 degrees and using the method of splice in silicone tube. The technological stages for obtaining grafted tomatoes have been established for the researched genotypes. These tomato combinations have been compatible for vegetable crops in protected spaces in the south area of Romania.
\end{abstract}

Keywords: Dutch scion, grafting, Solanum lycopersicum L., Romanian rootstocks

\section{Introduction}

The tomatoes are vegetables very much cultivated in the protected spaces from Romania. The grafting is an agronomic method that induces or improves plant vigor, resistance to soil diseases (Fusarium sp. and Vertillium sp.) and pests (Meloidogyne sp.), resistance to abiotic factors, quantity and quality of tomato yield.

The grafting has been developed because soil borne pathogens are a serious problem, that can be avoided by using resistant rootstocks (Doltu et al., 2015). Some cultivars are not able to adapt to protected cultivation, withstand soil born disease pressure and extreme changes in temperature and moisture (Leonardi and Romano, 2004).

The grafting can be performed successfully if the plants (scion and rootstock) have similar diametres (Doltu et al., 2013).

\section{Aims and objectives}

The aim of this experience has been to establish the technological stages (calendar dates and days between stages) for producing the 'Abellus' Dutch scion and the ' $\mathrm{L}_{542}$ ', ' $\mathrm{L}_{543}$ ' and ' $\mathrm{L}_{544}$ ' Romanian rootstocks, to obtain some plants with compatible phenotypes, similar diametres for grafting by plant cutting at 45 degrees.

\section{Materials and methods}

This experience has been realized in a greenhouse for grafted vegetable seedlings from the Horting Institute Bucharest in 2018.

The research was carried out on some tomato cultivars: a Dutch scion ('Abellus' $F_{1}$ hybrid) from Rijk Zwaan company and three Romanian rootstocks (' $\mathrm{L}_{542}$ ', ' $\mathrm{L}_{543}$ ' and ${ }^{2} \mathrm{~L}_{544}$ ') from the 
Table 1. Technological dates for obtaining of grafted tomato seedlings

\begin{tabular}{lccccccc}
\hline Sowing & & & Emergence & & Grafting & \multicolumn{2}{c}{ Callusing } \\
\hline & date & no. of days & date & no. of days & date & no. of days & date \\
\hline Rootstock 'L542' & 19.02 & 7 & 26.02 & $21 \mathrm{~b}$ & 18.03 & 7 & 25.03 \\
\hline Rootstock 'L543' & 19.02 & 7 & 26.02 & $21 \mathrm{~b}$ & 18.03 & 7 & 25.03 \\
\hline Rootstock 'L544' & 19.02 & 7 & 26.02 & $21 \mathrm{~b}$ & 18.03 & 7 & 25.03 \\
\hline Scion 'Abellus' & 26.02 & 5 & 03.03 & $18 \mathrm{a}$ & 18.03 & 7 & 25.03 \\
\hline Duncan test p<0,05 & & & & & & &
\end{tabular}

germplasm bank of the Research and Development Station for Vegetable Growing Buzău.

The plants have been obtained in alveolar plates (100 alveoli per plates and a capacity of 24 $\mathrm{ml}$ per alveoli) on peat substrate with a grain size 0-10 mm, NPK $\left(1 \mathrm{~kg} / \mathrm{m}^{3}\right)$, microelements $\mathrm{B}, \mathrm{Mg}$, $\mathrm{Cu}, \mathrm{Mn}, \mathrm{Zn}, \mathrm{Fe}, \mathrm{S}\left(0.050 \mathrm{~kg} / \mathrm{m}^{3}\right)$, chalk $\left(4.7 \mathrm{~kg} / \mathrm{m}^{3}\right)$, pH 6 and wetting agent $100 \mathrm{ml} / \mathrm{m}^{3}$.

'Abellus' is an early hybrid with indeterminate growth, red and spherical fruit, slightly flattened and average weight of $150-180 \mathrm{~g}$. It is cultivated in protected spaces and field.

' $\mathrm{L}_{542}{ }^{\prime},{ }^{\prime} \mathrm{L}_{543}$ ' and ' $\mathrm{L}_{544}$ ' are three tomato cultivars tested for approval as rootstocks.

The technology for obtaining of scion and rootstock seedlings has been according to the ecological requirements of the $S$. lycopersicum species.

Obtaining grafted tomato seedlings has involved following steps: sowing of scion and rootstocks, preparing for grafting, grafting, forming of callus, transferring of seedlings from the tunnel for callus forming in the growing space. After sowing, the plants have been increased in classic conditions for tomato seedlings.

The statistical analysis has been carried out by Duncan's test.

\section{Results and Discussion}

The scion and rootstocks have had similar diameters and so the grafting has been performed successfully by manual cutting at 45 degrees and splice in silicone tube.

The technological stages for obtaining grafted plants have been established on calendar dates and days for the researched tomato cultivars (Tab. 1).

The Duncan test shows that between rootstocks and scion have been small differences; the grafting has been made in 21 days ('L542', 'L543' and 'L544') and 18 days ('Abellus') from emergence of plants. The plants have had 2,5 mm diameters and 4 leaves at grafting. The grafting was performed successfully (95\% grafted plants/ rootstock cultivar). The optimum diameter is 1,5 $\mathrm{mm}$ (Bogoescu et al., 2008). The grafting of some Japanese hybrids was achieved after 16-18 days and 19-20 days from scion emergence and 13-14 days from the rootstock emergence (Doltu et al., 2013).

\section{Conclusion}

The technological steps have been set up to get a phenotypic compatibility of the plants at grafting moment; the plants (scion and rootstock) have had similar diameters for producing Dutch grafted tomato seedlings ('Abellus') on the Romanian rootstocks ('L542', 'L543' and 'L544').

Between the 'L542', 'L543' and 'L544' rootstocks and the 'Abellus' scion have been small differences at grafting. These new tomato combinations (Dutch scion $\times$ Romanian rootstocks) obtained by grafting at the Horting Institute in 2018 have been compatible for vegetable crops in the protected spaces from Romania.

\section{References}

1. Bogoescu M, Doltu M, Sora D, Iordache B (2008). Results on establishing the technology for obtaining the tomatoes grafted seedlings designed for greenhouses. Bulletin UASVM Horticulture Cluj-Napoca 65(1):147-152.

2. Doltu M, Bogoescu M, Sora D (2013). The influence of seed position on the emergence some rootstocks by Lagenaria siceraria. Bulletin UASVM Horticulture Cluj-Napoca 70(1):239-240.

3. Doltu M, Bogoescu M, Sora D (2013). Technological aspects concerning grafting of some Japanese tomatoes. Journal of Horticulture, Foresty and Biotechnology Timișoara 17(1) :62-65.

4. Doltu M, Bogoescu M, Sora D (2015). Results Concerning the Fusion Capacity of Some Cucurbits Grafted by Different Techniques. Bulletin UASVM Horticulture ClujNapoca 72(1):215-216.

5. Leonardi C, Romano D (2004). Recent issues on vegetable grafting. Acta Horticulture 631:163-174. 